\title{
FOOTBALL AS A MEANS OF PHYSICAL EDUCATION
}

\author{
Barno Pulatovna Abdullaeva
}

Lecturer, Chirchik State Pedagogical Institute Of Tashkent Region, Uzbekistan

\section{ABSTRACT}

This article discusses the effective teaching of football sports in the physical development of preschool children. Additionally, it is mentioned that, football exercises not only have a healthy effect on their healthy growth and development, but also on the leg and arm muscles of children in motion. And exercises that encourage children to move with the ball were also kept in mind.

KEYWORDS: - Preschoolers, football, physical development, muscles, ball movement, team sports, motor coordination, central nervous system, running, passing, catching the ball.

\section{INTRODUCTION}

In the existing programs for physical education in a preschool educational institution, the actions of children with a ball are included from the second year of life. They occupy a significant place among other means of physical education and become more complicated from group to group due to the introduction of additional tasks, as well as more complex ways of performing and using sports games with a ball according to simplified rules.

Exercises with the use of elements of sports games and football, in particular, contribute to the development of motor coordination abilities (balance, orientation in space, accuracy, rhythm, pace, dexterity, coordination of movements, responsiveness), endurance, speed, strength, flexibility. They form the skills of possession and performance of various actions with the ball, coordination of efforts with distance, and develop the expressiveness of movement. Children of preschool age still have poorly developed ability for precise movements, therefore, any actions with the ball have a positive effect on the development of this quality. Exercises and ball games, with the appropriate organization of their implementation, have a beneficial effect on the physical development and performance of the child. Exercises with balls of various weights and volumes develop not only large, but also small muscles of the legs and arms, increase joint mobility, which is especially important for older preschool children.

When using the elements of the game of football, the child performs actions with the ball with his feet (kicks on the ball with his feet, stopping (receiving) the ball, dribbling and feints, tackling) and with his hands (catching, throwing in, rolling, as well as special goalkeeper techniques, etc. .). At different stages of the game 
CURRENT RESEARCH JOURNAL OF PEDAGOGICS 2(8): 72-76, August

2021 DOI: https://doi.org/10.37547/pedagogics-crjp-02-08-16

ISSN 2767-3278

(C)2021 Master Journals

\section{Crossref do) 81 Google}

Accepted 26 th August, 2021 \& Published $31^{\text {th }}$ August, 2021

and when performing various tasks, proprioceptors of various muscles and receptors of touch are involved in movement. There is a close interaction with the enemy and partners, which contributes to a large number of tactiletactile sensations, as well as irritation of the vestibular apparatus. The auditory analyzer perceives the rhythm of steps, the sound of hitting the ball, instructions and prompts. The visual analyzer performs complex perceptions coordinated with the work of muscle proprioceptors. This promotes consistency in the work of the upper and lower extremities, which in turn has a positive effect on the harmonious development of the central nervous system and the whole organism. When teaching the elements of playing football, a wide variety of actions with the ball are used, which provides the necessary physical load on all muscle groups of the child, the muscles that hold the spine are especially important when forming the correct posture.

In collective ball games, favorable conditions are created for the upbringing of positive moral and volitional traits in children. Such games teach to overcome selfish impulses, bring up endurance. In play, the child always has the opportunity to test his strength and make sure that his actions are successful. Emotionality, dynamism, variety of actions and game situations in football attract older preschool children to this game.

The elementary actions of playing football can be widely used in the senior and pre-school kindergarten groups. In this case, the exercises can include both ball games and special exercises to consolidate the skills of ball possession. Teaching children the basic techniques of ball handling in playing conditions should have the goal of achieving favorable physical development and versatile physical fitness of children, as well as familiarizing children with football in an accessible form. Football is a sports game that requires appropriate physical, technical and tactical training of players, which is achieved through special and constant training. The main focus should not be on special training, but on the creation of general prerequisites for the successful teaching of sports games in school.

Formation of actions with a ball in preschool children when learning the elements of playing football.

An active game with a ball requires a certain tension in the mental activity of children: analyzing the situation, making a decision corresponding to the situation, anticipating the possible actions of the enemy. The game of football is a team game, the joint actions of the players in it are conditioned by a common goal. It is difficult and emotional, it includes fast running, dribbling, stopping, hitting, passing, catching, throwing in, feints, carried out in originally conceived combinations, carried out with the opposition of partners in the game.

Playing football differs from outdoor games in greater certainty. The composition of the teams is limited by a set number of participants, and the duration of the game is limited by a certain time. It has established rules that determine the accuracy of motional actions, and is carried out with the participation of a judge. The correct marking of the site, the appropriate equipment and inventory are mandatory.

The technique of playing football consists of two types of actions. One of them is characterized by movements performed without the ball and with the ball without passing it to a partner. These include: walking, running, jumping, turning, false movements. The second type of action is more specific to football - kicking the ball, receiving (stopping) the ball, dribbling and dribbling, tackling, as well as special goalkeeper techniques.

The most important principle for the selection of content for the initial teaching of the techniques of playing football for preschool children is the 
CURRENT RESEARCH JOURNAL OF PEDAGOGICS 2(8): 72-76, August

2021 DOI: https://doi.org/10.37547/pedagogics-crjp-02-08-16

ISSN 2767-3278

(C)2021 Master Journals

\section{Crossref do) 81 Google}

Accepted 26 $6^{\text {th }}$ August, 2021 \& Published 31 th August, 2021

selection of those actions with and without the ball, which:

Form the basis of the technique of any outdoor and sports ball game;

Available to older preschool children;

Give the most effective result in solving game problems.

The actions selected for learning must ensure that the tension of forces necessary for their assimilation corresponds to the level of development of the students.

To successfully master the actions with the ball, it is necessary to teach children such movement techniques as running, turning, stopping, as well as actions with the ball: passing the ball with the right foot and left foot, catching the ball, dribbling the ball with the right foot in a straight line with a change in direction, with the opposition of the other player hitting the ball.

At the beginning, the main task of training is the formation of certain skills to handle the ball, feel its properties and produce various movements in accordance with them. Therefore, during this period, it is advisable to give a lot of motor actions, as well as freely play with the ball. It is necessary to make sure that the children like the ball lessons, so that they remain satisfied after the games and look forward to the opportunity to play more. Fun, laughter are the constant companions of the child.

It is equally important to teach children to accept and in the future to maintain the defensive stance of a football player, since in this game each of its participants must at any time be ready to oppose the opponent's maneuver, including their unpredictable action. Having adopted such a stance, the defender is able to move in any direction and at such a speed that allows him to effectively control the actions of the attackers, i.e. quickly maneuver on the site. Protective stance is the position of the player on the legs apart at shoulder-width apart, bent at the knee joints. The player's hands are located just below the waist, helping to maintain balance, the back does not strain, and the weight of the body is distributed to both legs.

After children learn how to correctly perform a protective stance, move around the site, you can teach them how to receive (stop) the ball, starting with mastering the reception of rolling balls (with the inner side of the foot and instep, chest, head, etc.), then go to learning the reception of the ball by various parts of the body in motion and in a jump. In football, reception (stopping) of the ball is achieved by a shockabsorbing movement of one or another part of the body, by relaxing certain muscle groups, as well as by covering the ball with the foot, stomach, and lower leg.

The intensity of the game, the increased speed actions of the players, which distinguish this sport, do not allow the players to completely stop it when receiving the ball. As a rule, the players are forced in the game to immediately transfer the ball to a comfortable position for subsequent playing actions. Transfers are carried out in one direction or another, as well as behind the back.

The implementation of the reception (stopping) of the ball, as well as other elements of football in different conditions, in combination with other actions, contribute to the improvement of the studied action, the ability to further independently apply it in game situations.

In parallel with the reception (stopping) of the ball, it is necessary to teach children to dribble, or dribbling (performed by the outer part of the instep, the inside of the instep, the inside of the foot, the middle of the foot, toe and sole). It is used in football to get the player in possession of the ball into an advantageous position to make a pass to a partner or kick on goal. In soccer, dribbling is done with both feet. When dribbling, the player slightly tilts the upper body forward, 
CURRENT RESEARCH JOURNAL OF PEDAGOGICS 2(8): 72-76, August

2021 DOI: https://doi.org/10.37547/pedagogics-crjp-02-08-16

ISSN 2767-3278

(C)2021 Master Journals

Crossref dof 81 Google

Accepted $26^{\text {th }}$ August, 2021 \& Published 31 th August, 2021

thus covering the ball from opponents. At the same time, the gaze should not be constantly riveted to the ball, since the football player must simultaneously visually control the movements of partners and opponents around the court, acting in accordance with the developing game situation. Then, children should be taught to correctly kick the ball with their feet - the basis of the technique of playing football. Players have to perform kicks on the ball in a variety of situations and positions, on motionless, rolling, flying balls - from a place, in motion, in a jump, in a fall, with turns, etc.

In football, players often have to perform deceptive moves - feints. The goal of these tactics is to save the ball, beat the opponent, and get rid of his guardianship. Feints are performed both with the torso and with the legs. When performing them, various options for leaving with the ball (forward, backward, and left), removing the ball, and passing the ball to a partner, as well as their combinations are used.

The elements of the game of football also include the basic techniques of tackling the ball from an opponent. Tackling, as a rule, is carried out when the opponent receives the ball, during dribbling, as well as when trying to shoot at goal or pass the ball to a partner. Noticing that the opponent has lost control of the ball for a moment or has released the ball too far away from him, the defending player takes a dash towards the ball. The selection is carried out depending on the location of the opposing players relative to each other: front, side or back-side.

\section{ReFERENCES}

1. Умарова 3.А. Бошланғич таълимда педагогик жараён. // Муғаллим хам узликсиз билимлендириў. Илмийметодик журнал. ISSN 2181-7138. №1 2021 й. 70-74-бет.

2. Mamadaliyev K.R., Jabborova O.M.,
Umarova Z.A., Abdullaeva B.P. Creation of a New Generation of Teaching Literature -A Requirement of Modernity // SCOPUS International Journal of Psychosocial Rehabilitation, Vol. 24, Special Issue 1, 2020.

3. Жабборова Онахон Маннаповна, Ташпулатова Дилором Мукимовна, Бошланғичсинфўқитувчиларигақўйила диганталаблар. Academic research in educational sciences, Issue 3, 2021, pp 575-5827.

4. Жабборова О.М., Умарова З.А. Тарбия фанини кластер усулида ўқитишдапедагогикконфликтларнибар тарафэтиш. Academic research in educational sciences, Issue 1, 2021, pp 582-587.

5. Наримбетова З.А. УЧИТЕЛЬНРАВСТВЕННЫЙ ПРИМЕР ДЛЯ УЧЕНИКА. ACADEMIC RESEARCH IN EDUCATIONAL SCIENCES VOLUME 2

6. | Кузманова Г.Б., Н.А.Бекетов Use of Historical Materials In Teaching Mathematics In Continuous Education. The american journal of social science and education innovations, Volume 2 Issue 9, 2020, ISSN 2689-100X, 2(09), 531537.12.14.

7. Кузманова Г.Б.UMUMIY O’RTA TA'LIM MAKTABLARIDA MATNLI MASALALARNING TA'LIMIY AHAMIYATI. ACADEMIC RESEARCH IN EDUCATIONAL SCIENCES, 2(3), 1154-1159

8. Abdullaeva B.P. Corruption in the field of education: assessments and ways to address. "Тенденции и перспективи развития науки и образования в условиях глобализации".Международной научнопрактической интернет-конференции. 
CURRENT RESEARCH JOURNAL OF PEDAGOGICS 2(8): 72-76, August

2021 DOI: https://doi.org/10.37547/pedagogics-crjp-02-08-16

ISSN 2767-3278

(C)2021 Master Journals

Crossref dof 81 Google

Accepted $26^{\text {th }}$ August, 2021 \& Published 31 th August, 2021

г.Переяслав, Украина.2020 год 30

9. Abdullaeva B.P. Babaraximova B.P. Pardaev B.P.Using information and communication technologies in teaching process of various primary European Journal of Research and Reflection in Educational Sciences, 8 (10), 67-70. Progressive Academic Publishing, UKwww.idpublications.org 14.10.2020.

10. Abdullaeva B.P. Abdullaev F.T. Organization of Swimming Lessons In Preschool Institutions THE AMERICAN JOURNAL OF SOCIAL SCIENCE AND EDUCATION INNOVATIONS. JULY 2020[ TAJSSEI]322ISSN (e):2689-100X DOI: https://doi.org/10.37547/tajssei/Volume 02Issue 07-423.

11. Abdullayeva, B.P., \& Babaraximova, B. P. (2020). MAKTABGACHA TA'LIM MUASSASASIDA FUTBOL DARSLARINI TASHKIL ETISH METODIKASI. Academic Research in Educational Sciences http://ares.uz/jurnallarsahifasi/ares-vol-1-no-3-2020.

12. Abdullaeva B.P. ACADEMICIA: An International Multidisciplinary Research Journal https://saarj.com ORGANIZATION AND METHODOLOGY OF CONDUCTING FOOTBALL LESSONS IN A PRESCHOOL INSTITUTION 650-655 10.5958/2249-7137.2021.00098.

13. Abdullaeva B.P. Teaching A Child To Play Football From A Youth. The American Journal of Interdisciplinary Innovations and Research (ISSN-26427478)Published:April 30, 2021Pages:147151Doi:https://doi.org/10.37547/tajiir/V olume03Issue04-24MPACT FACTOR2021:5.6760CLC-1091588944. tashkilotlarida futbol elementlarini o'rgatishda qo'llaniladigan asosiy mezonlar. Экономика и социум" №4(83) 2021.

14. Abdullaeva B.P. Maktabgacha ta'lim 